\title{
Pengoptimuman Proses Penyemperitan Gentian Karbon Terkisar dan Polipropilena Bagi Komposit Polimer Pengalir
}

(Optimization of Milled Carbon Fibre Extrusion and Polypropylene Process for Conductive Polymer Composite)

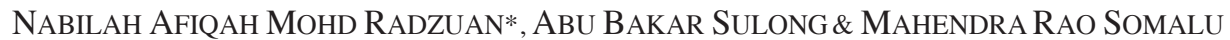

\begin{abstract}
ABSTRAK
Proses penyemperitan merupakan salah satu proses pra-pencampuran yang dapat membantu meningkatkan tahap serakan bahan pengalir dalam komposit polimer pengalir (CPC). Tahap keberaliran elektrik dilihat tidak begitu memuaskan walaupun telah melalui proses serakan melalui pengacuan mekanik. Kajian ini dijalankan bagi mengoptimumkan proses penyemperitan bahan gentian karbon terkisar (MCF) dan polipropilena (PP) iaitu suhu penyemperitan dan halaju putaran melalui kaedah reka bentuk eksperimen (Taguchi). Susunan orthogonal Taguchi L digunakan bagi menentukan aras yang paling optimum serta menjalankan analisis varian bagi memperoleh nilai keberaliran elektrik yang paling baik. Pengoptimuman parameter pada suhu penyemperitan $210^{\circ} \mathrm{C}$ hingga $250^{\circ} \mathrm{C}$ dan halaju putaran 50 hingga $90 \mathrm{rpm}$ menggunakan komposisi bahan sebanyak $80 \%$ bt. MCF dan $20 \%$ bt. PP dengan tahap keberaliran elektrik meningkat pada tahap maksimum $3.67 \mathrm{~S} / \mathrm{cm}$. Pengoptimuman parameter ini menunjukkan bahawa reka bentuk eksperimen yang terhasil mampu menghasilkan nilai keberaliran elektrik yang tinggi serta mempunyai sifat mekanik yang baik.
\end{abstract}

Kata kunci: Gentian karbon terkisar; kaedah reka bentuk eksperimen; keberaliran elektrik; penyemperitan; ujian mekanik

ABSTRACT

The extrusion process is one of the pre-mixing processes that aid in improving the filler dispersion in conductive polymer composite (CPC). Electrical conductivity level still needs much improvement in mixing process through mechanical mixer. This study was conducted to optimise the extrusion process parameters (temperature and rotational speed) of milled carbon fibre (MCF) and polypropylene (PP) using experimental design (Taguchi method). Orthogonal array design of $L_{9}$ is adapted in this study to determine the optimum level and measuring performance via variance analysis to obtain the maximum electrical conductivity. The optimum working conditions for $80 \mathrm{wt}$. \% of MCF and $20 \mathrm{wt}$ \% of PP composition were determined at the extrusion temperature of $230^{\circ} \mathrm{C}$ to $250^{\circ} \mathrm{C}$ and a rotational speed of 50 to $90 \mathrm{rpm}$ in which the electrical conductivity increases to the maximum value of $3.67 \mathrm{~S} / \mathrm{cm}$. Optimisation of these parameters is expected to produce a robust design with improved electrical conductivity and mechanical properties.

Keywords: Design experiment; electrical conductivity; extrusion; mechanical testing; milled carbon fibre

\section{PENGENALAN}

Komposit polimer pengalir (CPC) telah digunakan secara meluas dalam pelbagai bidang memandangkan sifatnya yang baik terutamanya dalam kerintangan haba, sifat mekanik dan rawatan kimia (Balogun \& Buchanan 2010; Dweiri \& Sahari 2008; Feller et al. 2003, 2002; Li et al. 2015; Suherman et al. 2013; Sulong et al. 2013). CPC merupakan campuran pengisi pengalir seperti gentian karbon, karbon hitam, grafit, grafen, karbon nano-tiub dengan matriks polimer yang terdiri daripada termoplastik dan termoset (Antunes et al. 2011). Bahan komposit ini direka bentuk dan diproses bagi memperoleh nilai keberaliran elektrik yang tinggi berdasarkan penggunaannya dalam aplikasi seperti plat dwi kutub dalam sel fuel. Pada umumnya, tahap keberaliran elektrik bergantung kepada pecahan isi padu pengisi pada kedudukan melepas ambang perkolasi dengan tahap keberaliran elektrik meningkat sehingga mencapai takat malar. Keadaan ini disebabkan oleh rangkaian beralir telah menjadi lengkap dan aliran elektron dapat melalui rangkaian tersebut dengan adanya penambahan isi padu pengisi (Balogun \& Buchanan 2010; Suherman et al. 2013a, 2013b; Zakaria et al. 2015).

Walau bagaimanapun, tahap keberaliran elektrik bahan komposit polimer pengalir tidak hanya bergantung kepada pecahan isi padu pengisi sahaja. Namun terdapat beberapa faktor lain antaranya bentuk dan saiz pengisi, penyerakan pengisi dalam matriks polimer, orientasi pengisi, kadar ricih serta morfologi bahan (Antunes et al. 2011). Oleh itu, pengoptimuman kaedah pemprosesan merupakan langkah yang mampu meningkatkan nilai keberaliran elektrik dan sifat mekanik bahan komposit polimer pengalir. Kini, kaedah pengacuan tekanan dan kaedah pengacuan suntikan adalah kaedah yang sering digunakan bagi membentuk bahan polimer komposit (Barton et al. 2008, 2007; Dweiri \& Sahari 2008; Kakati et al. 2011, 2009; Merzouki \& Haddaoui 2012). Walaupun kaedah ini telah digunakan dengan meluas, namun kajian menunjukkan bahawa kaedah pra-pencampuran dapat membantu 
dalam meningkatkan sifat mekanik dan nilai keberaliran elektrik bahan polimer komposit (Jimenez \& Jana 2007; Suherman et al. 2013a; Suherman et al. 2013b; Zakaria et al. 2015). Proses pra-pencampuran ini penting bagi membolehkan serakan bahan pengisi adalah sekata dalam matriks polimer, daya ricih yang sederhana terhasil serta meningkatkan kebolehan untuk membentuk matriks yang homogen apabila bercampur dengan resin polimer (Dweiri \& Sahari 2008; Hu et al. 2008). Proses penyemperitan adalah salah satu kaedah pra-pencampuran menggunakan penyemperit skru berkembar merupakan salah satu kaedah bagi menghasilkan komposit dengan serakan bahan pengisi yang tinggi. Penyemperit skru berkembar digunakan secara meluas dalam bidang industri khasnya seperti pemprosesan polimer, pemprosesan makanan serta bahan yang berkelikatan tinggi memandangkan keupayaannya dalam melakukan beberapa proses seperti pemanasan, leburan, pencampuran dan tindak balas secara serentak (Nakayama et al. 2011).

Parameter penyemperitan seperti halaju putaran dan suhu harus diambil kira dalam mengoptimumkan proses penyemperitan. Oleh itu, uji kaji yang menyeluruh diperlukan untuk mengkaji kesan setiap parameter terhadap tahap keberaliran elektrik dan kaedah pengoptimumannya. Kaedah susunan orthogonal Taguchi diadaptasi bagi menilai prestasi keseluruhan komposit polimer pengalir (Chua et al. 2013). Analisis varian (ANOVA) dijalankan bagi mengenal pasti aras optimum untuk setiap parameter yang dikaji. Antara kelebihan kaedah Taguchi selain daripada dapat meminimumkan kos penyelidikan adalah keupayaannya untuk mengurangkan variasi pada respons parameter serta menjadikan purata respons parameter sebagai sasaran (Kaytakoğlu \& Akyalçın 2007). Bagi memastikan komposit polimer yang terdiri daripada polipropilena dan kisaran gentian karbon mempunyai tahap keberaliran elektrik yang tinggi, parameter yang optimum merangkumi suhu dan halaju putaran proses penyempritan dikaji menggunakan kaedah penyelidikan Taguchi. Keputusan uji kaji dalam kajian ini dianalisis dalam orentasi kedudukan pengisi adalah selari dengan arah penyemperitan.

\section{EKSPERIMEN KAJIAN}

\section{BAHAN}

Kisaran gentian karbon (MCF) diperoleh dari syarikat Shen Zhen Yataida High-Tech. Co., Ltd dengan saiz diameter $9 \mu \mathrm{m}$ dan purata panjang keseluruhan $300 \mu \mathrm{m}$, nisbah bidang adalah 43 manakala ketumpatan bahan adalah $1.75 \mathrm{~g} / \mathrm{cm}^{3}$ seperti dilaporkan oleh pembekal. Gentian karbon jenis ini mampu meningkatkan tahap keberaliran elektrik pada nilai bebanan yang rendah serta tahap serakan pengisi yang sekata dalam matriks polimer melalui proses penyempritan. Selain itu, nisbah bidangnya yang tinggi turut membantu meningkatkan keberaliran elektrik dalam matriks polimer (Barton et al. 2008; Köpplmayr et al. 2013). Polipropilena (PP) dengan gred Titan (600) mempunyai purata saiz maksimum $90 \mathrm{~m}$, ketumpatan bahan sebanyak $0.91 \mathrm{~g} / \mathrm{cm}^{3}$ serta indeks cairan sebanyak $10 \mathrm{~g} / 10 \mathrm{~min}$ pada suhu 160 adalah dibekalkan oleh Goonvean Fibers Ltd. Polypropylene. Pemilihan PP jenis ini disebabkan oleh sifatnya yang menarik seperti mempunyai kekuatan mekanik yang baik, tahap ketumpatan yang rendah, kerintangan elektrik yang baik dan kebolehtelapan gas yang baik (Antunes et al. 2011).

\section{PENYEDIAAN KOMPOSIT MCF/PP}

Komposisi bahan komposit pengalir MCF/PP yang digunakan dalam kajian ini adalah bernisbah 80/20 mengikut peratus berat (Taherian et al. 2013). Bahan komposit pada awalnya melalui proses pra-pencampuran secara fizikal pada suhu bilik menggunakan pengacuan mekanik, model RM20-KIKA-WERK pada halaju putaran $1200 \mathrm{rpm}$ selama $60 \mathrm{~s}$ sebelum melalui proses pencampuran leburan menggunakan mesin penyemperitan, Thermo Haake TSE.

\section{PROSES PENYEMPERITAN}

Proses penyemperitan dilakukan menggunakan alat penyemperitan skru berkembar, Thermo Haake TSE yang mempunyai 6 modul sepanjang $100 \mathrm{~mm}$ setiap satu. Modul tersebut disambungkan dengan sistem pemanas dan penyejuk dan suhu penyemperitan dikawal sepanjang proses penyemperitan dijalankan. Halaju putaran ditetapkan kepada masing-masing 50, 70 dan 90 rpm, manakala suhu penyemperitan ditetapkan kepada $190^{\circ} \mathrm{C}$, $230^{\circ} \mathrm{C}$ dan $270^{\circ} \mathrm{C}$ (Hine et al. 1995; Taipalus et al. 2001; Takeda et al. 2011; Tungjitpornkull \& Sombatsompop; Wang et al. 2011). Pengacuan mampat berdiameter $5 \mathrm{~mm}$ digunakan dalam kajian ini. Selepas melalui proses penyemperitan, bahan komposit MCF/PP dipotong selari dengan arah penyemperitan sebelum melalui proses pencirian komposit. Parameter kajian dioptimumkan melalui kaedah Taguchi menggunakan tiga aras parameter yang berbeza seperti dalam Jadual 1. Parameter yang sepadan dengan paras kajian tersebut dipilih berdasarkan uji kaji awal yang dijalankan. Susunan orthogonal $\mathrm{L}_{9}\left(3^{2}\right)$ merupakan aturan yang bersesuaian bagi menganggarkan keputusan uji kaji yang optimum. Reka bentuk uji kaji yang dijalankan dijadualkan seperti dalam Jadual 2. Prestasi keseluruhan adalah dipengaruhi oleh parameter yang dikawal dan tidak dikawal (faktor hingar) dengan kaedah Taguchi membantu dalam mengurangkan output varian walau dengan kehadiran faktor hingar bagi memperoleh reka bentuk uji kaji yang sempurna. Terdapat tiga kategori pengoptimuman iaitu nominal yang terbaik, kecil lebih baik dan besar lebih baik. Pengoptimuman menggunakan kategori besar lebih baik digunakan dalam kajian ini bagi memperoleh hasil yang maksimum iaitu tahap keberaliran elektrik bagi komposit polimer pengalir yang paling tinggi (Kaytakoğlu \& Akyalçın 2007). 
JADUAL 1. Parameter yang sepadan dengan aras kajian

\begin{tabular}{ccccc}
\hline & & \multicolumn{3}{c}{ Aras } \\
& Parameter & 1 & 2 & 3 \\
\hline A & Suhu $\left({ }^{\circ} \mathrm{C}\right)$ & 210 & 230 & 250 \\
B & Halaju putaran $(\mathrm{rpm})$ & 50 & 70 & 90 \\
\hline
\end{tabular}

\section{PENCIRIAN KOMPOSIT POLIMER PENGALIR}

Tahap keberaliran elektrik arah satah (in-plane) bagi komposit polimer pengalir pada arah selari dengan arah penyemperitan diukur menggunakan alat Jandel pelbagai ketinggian proba empat takat dan nilai bacaan diambil menggunakan RM3 Test Unit (Dweiri \& Sahari 2007; Suherman et al. 2013a; Suherman et al. 2013b; Zakaria et al. 2015).

\section{ANALISIS PEMETERAAN GRAVITI HABA (TGA)}

Analisis pemetraan graviti haba (TGA) dijalankan bagi menentukan pencirian kestabilan terma. Uji kaji TGA dilakukan bagi mengukur perubahan berat dan takat lebur bahan berdasarkan perubahan suhu yang dikenakan pada suatu bahan. Alat Mettler Toledo (Model TGA 851e) digunakan bagi mengukur kestabilan terma bahan asal polimer (PP), gentian karbon (CF) dan bahan komposit polimer pengalir. Sampel dipanaskan daripada suhu 25 hingga 900 dengan kadar pemanasan 20/min dalam kehadiran gas nitrogen (Suherman et al. 2013).

\section{PEMBELAUAN SINAR-X (XRD)}

Bagi mengesan kehadiran komposisi yang terhasil kesan daripada proses penyemperitan uji kaji pembelauan sinar-X dijalankan menggunakan alat Bruker AXs Germany, model D8 Advance dengan pemecutan voltan $40 \mathrm{kV}, 40 \mathrm{~mA}$ menggunakan anode daripada bahan kumprum $(\mathrm{Cu})$.

\section{PEMERHATIAN MIKROSTRUKTUR}

Bagi mengenal pasti orientasi pengisi yang terhasil daripada proses penyemperitan, ujian pemerhatian mikroskop menggunakan alat mikroskop imbasan elektron FESEM, Model Supra 55/55VP dengan julat pembesaran $500 \times$ hingga $1000 \times$ digunakan dengan pemecutan voltan 0.1 hingga $30 \mathrm{Kv}$ (Suherman et al. 2013a; Suherman et al. 2013b).

\section{KEPUTUSAN DAN PERBINCANGAN}

\section{PENGOPTIMUMAN PARAMETER PENYEMPERITAN}

Kaedah Taguchi digunakan bagi mengurangkan varian dalam uji kaji melalui pengoptimuman tetapan parameter bagi memperoleh nilai keberaliran elektrik komposit polimer pengalir yang maksimum (Arslanoglu \& Yigit 2016; Pourjafar et al. 2013). Data uji kaji keberaliran elektrik yang diperoleh seterusnya dianalisa menggunakan perisian Minitab. Susunan orthogonal $\mathrm{L}_{9}$ direkodkan dalam Jadual 2. Pengulangan nilai bacaan keberaliran elektrik yang telah direkodkan kemudiannya diubah kepada nilai tunggal menggunakan nisbah SN bagi menggambarkan jumlah varian yang hadir serta respons bagi min (Ibrahim et al. 2010). Seterusnya, interaksi antara parameter A dan B dianalisa menerusi analisis varian (ANOVA) bagi menentukan sumbangan oleh setiap parameter (Arslanoglu \& Yigit 2016; Kaytakoğlu \& Akyalçın 2007). Jadual 3 menunjukkan perincian keputusan bagi analisis varian dengan halaju putaran merupakan parameter yang paling banyak menyumbang kepada keseluruhan keberaliran elektrik dengan $61.5 \%$ sumbangan daripada jumlah keseluruhan.

Rajah 1 menunjukkan kesan utama plot bagi nisbah SN dengan pengoptimuman parameter adalah berdasarkan puncak tertinggi untuk setiap parameter A dan B. Nisbah SN dalam Jadual 2 digunakan bagi membangunkan plot

JADUAL 2. Susunan orthogonal Taguchi $\mathrm{L}_{9}$ yang menunjukkan nilai keberaliran elektrik

\begin{tabular}{ccccc}
\hline Bil & \multicolumn{2}{c}{ Parameter } & $\sigma$ & $\mathrm{S} / \mathrm{N}$ \\
& $\mathrm{A}$ & $\mathrm{B}$ & $(\mathrm{S} / \mathrm{cm})$ & $(\mathrm{dB})$ \\
\hline 1 & 1 & 1 & 3.35 & 8.00 \\
2 & 1 & 2 & 0.95 & -0.45 \\
3 & 1 & 3 & 0.32 & -10.10 \\
4 & 2 & 1 & 3.67 & 11.24 \\
5 & 2 & 2 & 0.65 & -3.88 \\
6 & 2 & 3 & 0.39 & -8.20 \\
7 & 3 & 1 & 0.80 & -2.03 \\
8 & 3 & 2 & 0.33 & -9.70 \\
9 & 3 & 3 & 0.48 & -6.41 \\
& & & & -21.53 \\
& & & & -2.39 \\
\hline
\end{tabular}


JADUAL 3. Keputusan analisis varian bagi nilai keberaliran elektrik selari dengan arah penyemperitan

\begin{tabular}{ccccccc}
\hline Varian & DF & $\begin{array}{c}\text { Hasil tambah } \\
\text { kuasa dua (s) }\end{array}$ & Varian & $\begin{array}{c}\text { Nisbah } \\
\text { varian, F }\end{array}$ & $\begin{array}{c}\text { Hasil tambah kuasa } \\
\text { dua tulen, S' }\end{array}$ & $\begin{array}{c}\% \\
\text { sumbangan }\end{array}$ \\
\hline (A) & 2 & 2.0756 & 1.0378 & 4.7585 & 1.6394 & 11.75 \\
(B) & 1 & 8.80 & 8.8 & 40.349 & 8.5819 & 61.51 \\
(A)x(B) & 2 & 2.4224 & 1.2112 & 5.5534 & 1.9862 & 14.24 \\
Ralat & 3 & 0.6542 & 0.2181 & 1 & 1.7447 & 12.5 \\
Jumlah & 8 & 13.952 & & & & 100 \\
\hline
\end{tabular}

kesan utama. Daripada Rajah 1, halaju putaran merupakan parameter yang paling berpengaruh dalam mengoptimumkan proses penyemperitan. Hal ini disebabkan oleh pada halaju putaran $50 \mathrm{rpm}$, ia mengaruh pengisi untuk mengorentasi dan menjajar selari dengan arah penyemperitan (Ausias et al. 1996; Fan \& Advani 2005; Hobbie et al. 2003; Pötschke et al. 2004). Selain itu, pada halaju putaran yang melebihi $50 \mathrm{rpm}$, pengisi pengalir mula patah ketika proses penyemperitan dijalankan dan menyebabkan nilai keberaliran elektrik turun secara mendadak (Taipalus et al. 2001). Keadaan ini adalah disebabkan oleh pada halaju putaran yang tinggi, kadar ricih yang terhasil turut tinggi seperti ditunjukkan dalam Rajah 2. Peningkatan kadar ricih ini mendorong kepada kepatahan berlaku apabila tegasan ricih yang banyak dipindahkan kepada pengisi pengalir dalam matriks polimer. Keadaan yang sama dapat dilihat pada gentian kaca panjang dalam kajian terdahulu apabila lebih banyak pengisi mengalami kepatahan pada kadar ricih yang tinggi sekaligus menjejaskan nilai keberaliran elektrik (Wang et al. 2011).

\section{KESAN PENYEMPERITAN TERHADAP SIFAT MEKANIK DAN KEBERALIRAN ELEKTRIK}

Kesan proses penyemperitan terhadap komposisi bahan MCF/PP ditunjukkan dalam Rajah 3. Peningkatan suhu dan halaju putaran tidak memberi kesan terhadap komposisi komposit. Melalui uji kaji pembelauan sinar-X dapat dipastikan bahawa komposisi gentian karbon adalah melebihi komposisi polipropilena. Lengkungan TGA bagi komposit, polipropilena serta gentian karbon berkisar ditunjukkan dalam Rajah 4. Suhu peralihan degradasi bagi polipropilena adalah pada $300^{\circ} \mathrm{C}$ dan meningkat kepada $350^{\circ} \mathrm{C}$ hingga $360^{\circ} \mathrm{C}$ bagi komposit MCF/PP. Peralihan suhu ini menunjukkan komposit MCF/PP mempunyai potensi tinggi digunakan pada aplikasi bersuhu rendah serta bersuhu tinggi. Ini kerana suhu operasinya yang stabil sehingga $350^{\circ} \mathrm{C}$. Rajah 4 juga menunjukkan kehilangan berat kesan degradasi pada suhu $300^{\circ} \mathrm{C}$ hanya sebanyak $0.25 \%$ disebabkan oleh peningkatan kestabilan terma bahan komposit (Suherman et al. 2013).

Rajah 5 menunjukkan nilai keberaliran elektrik bagi komposit pengalir MCF/PP dengan nilai keberaliran maksimum adalah pada halaju penyemperitan $50 \mathrm{rpm}$. Semakin meningkat halaju putaran, semakin tinggi tegasan ricih dikenakan ke atas komposit menyebabkan gentian karbon cenderung untuk patah lebih banyak. Keadaan ini sekali gus mengurangkan keberaliran elektrik serta menurunkan sifat kekuatan bahan (Tungjitpornkull \& Sombatsompop 2009; Wang et al. 2011). Oleh itu, halaju putaran yang optimum sangat penting memandangkan

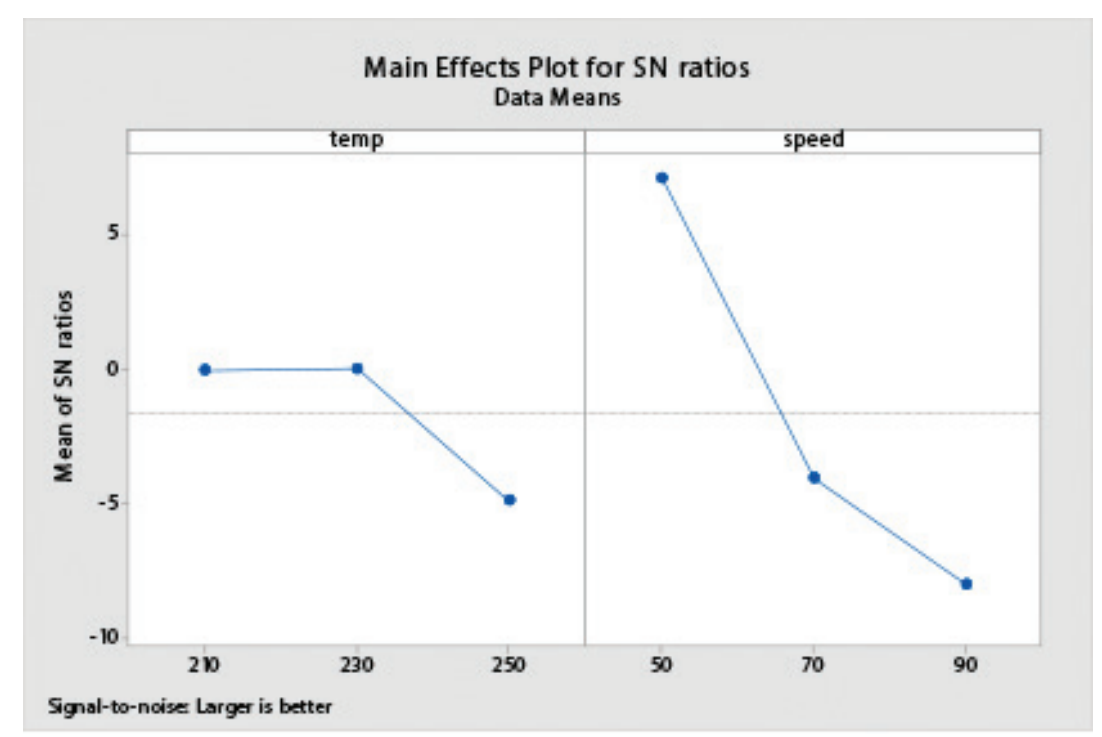

RAJAH 1. Plot kesan utama nisbah SN bagi nilai keberaliran elektrik selari dengan arah penyemperitan 


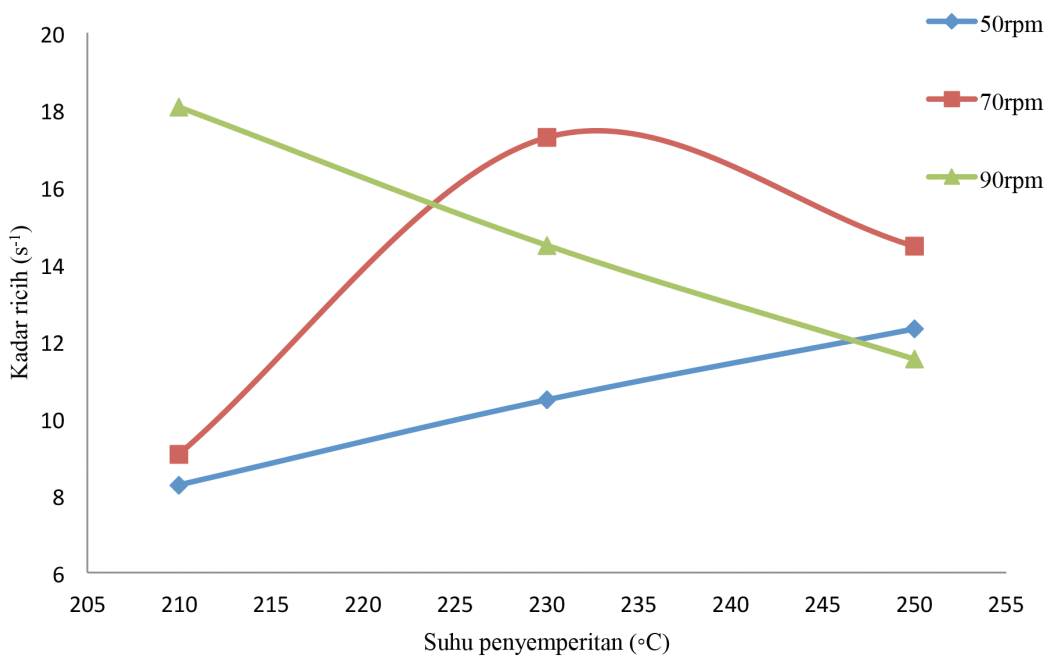

RAJAH 2. Kadar ricih bagi komposit MCF/PP

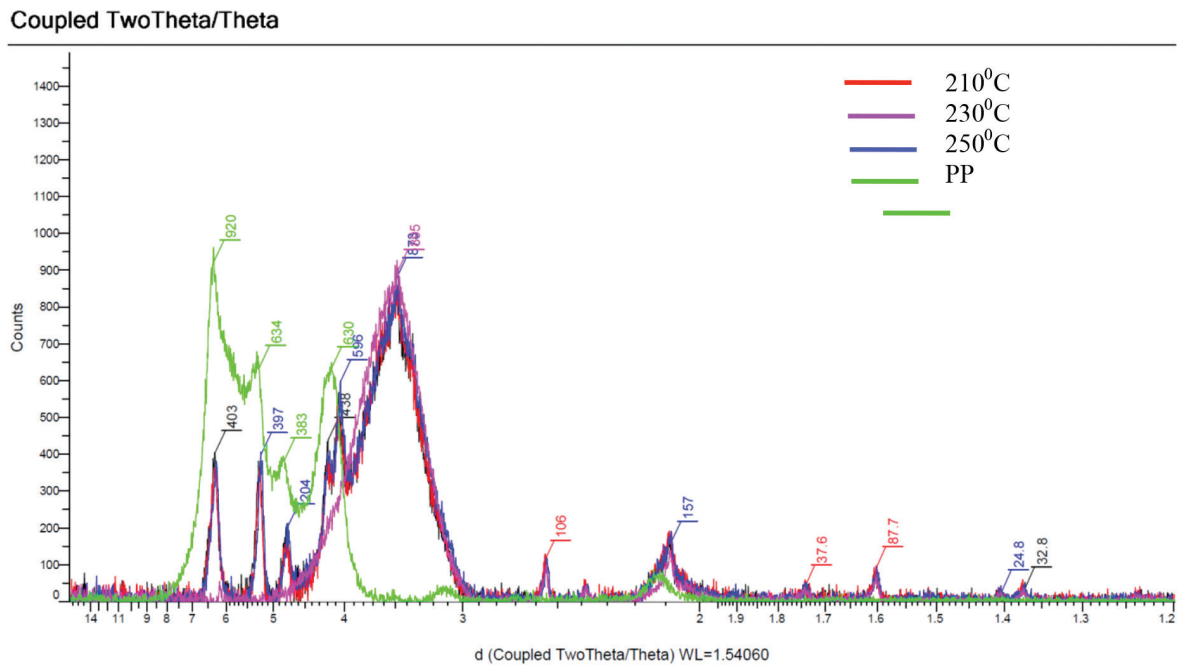

RAJAH 3. Komposisi MCF/PP bagi suhu $210,230,250^{\circ} \mathrm{C}$ dan polipropilena

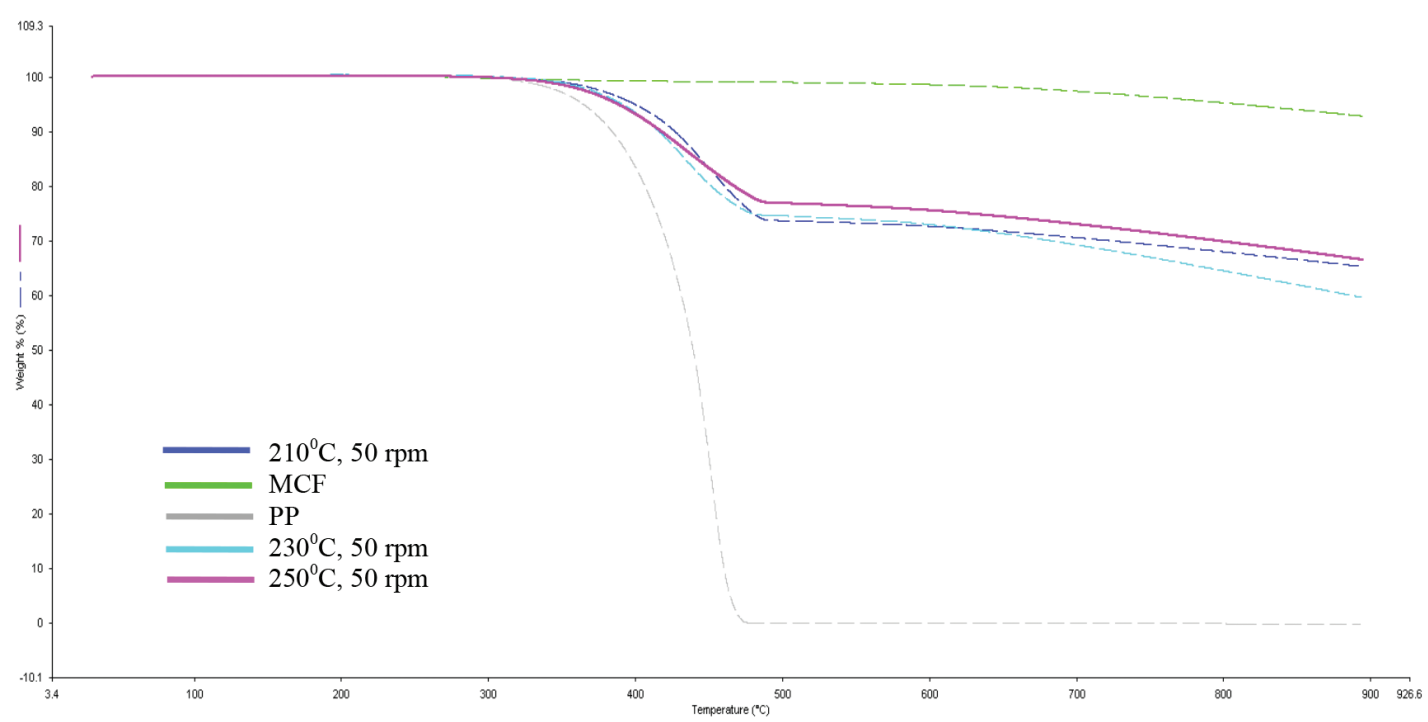

RAJAH 4. Lengkungan TGA bagi komposit MCF/PP 


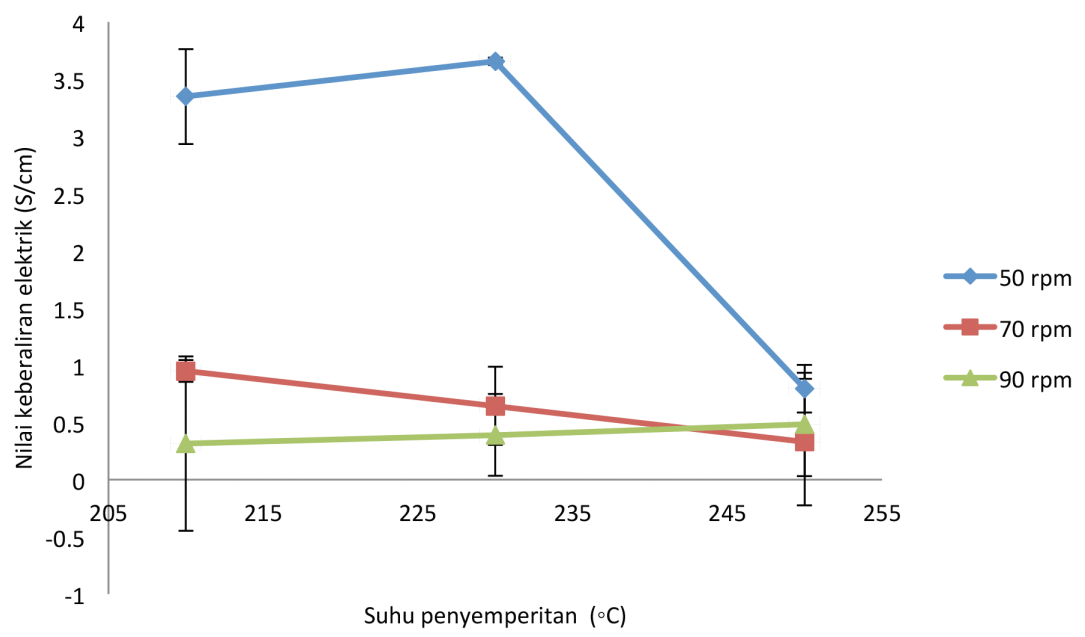

RAJAH 5. Nilai keberaliran elektrik bagi komposit MCF/PP

halaju putaran yang terlalu rendah mengurangkan orientasi pengisi serta menyukarkan proses penyemperitan.

Analisis pemerhatian mikrostuktur dalam Rajah 6 menunjukkan komposit polimer pengalir MCF/PP dalam suhu berbeza dengan pada suhu $210^{\circ} \mathrm{C}$ tahap keberaliran elektrik lebih rendah berbanding pada suhu $230^{\circ} \mathrm{C}$ seperti dalam Rajah 5. Keadaan ini ditunjukkan dalam Rajah 6(a) dengan pengisi tidak bersambung secara hujung ke hujung sebaliknya bersambung dalam keadaan badan ke badan serta badan ke hujung mengakibatkan tahap keberaliran elektrik yang lebih rendah. Berbeza dengan pengisi dalam Rajah 6(b) dengan pengisi kebanyakannya bersambung hujung ke hujung (Taipalus et al. 2001). Pengisi yang mempunyai sambungan yang sempurna membolehkan jaringan keberaliran elektrik dapat terbentuk (Antunes et al. 2011; Yusoff et al. 2010). Selain itu, polipropilena yang tidak berserak dan melebur dengan sekata juga mengurangkan nilai keberaliran elektrik komposit seperti

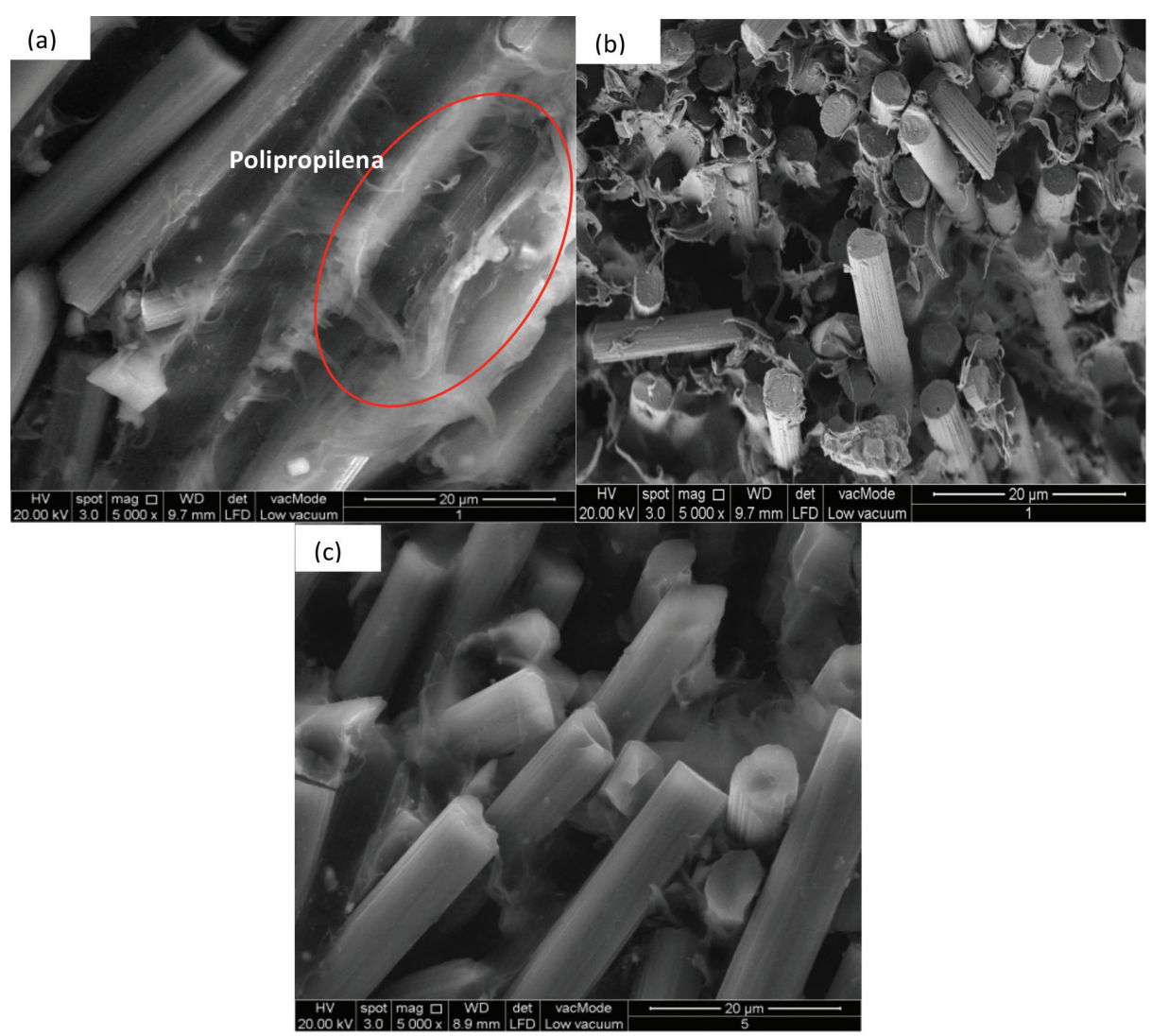

RAJAH 6. Gambarajah SEM bagi MCF/PP pada $50 \mathrm{rpm}$ dan suhu penyemperitan (a) $210^{\circ} \mathrm{C}$, (b) $230^{\circ} \mathrm{C}$ dan (c) $250^{\circ} \mathrm{C}$ 


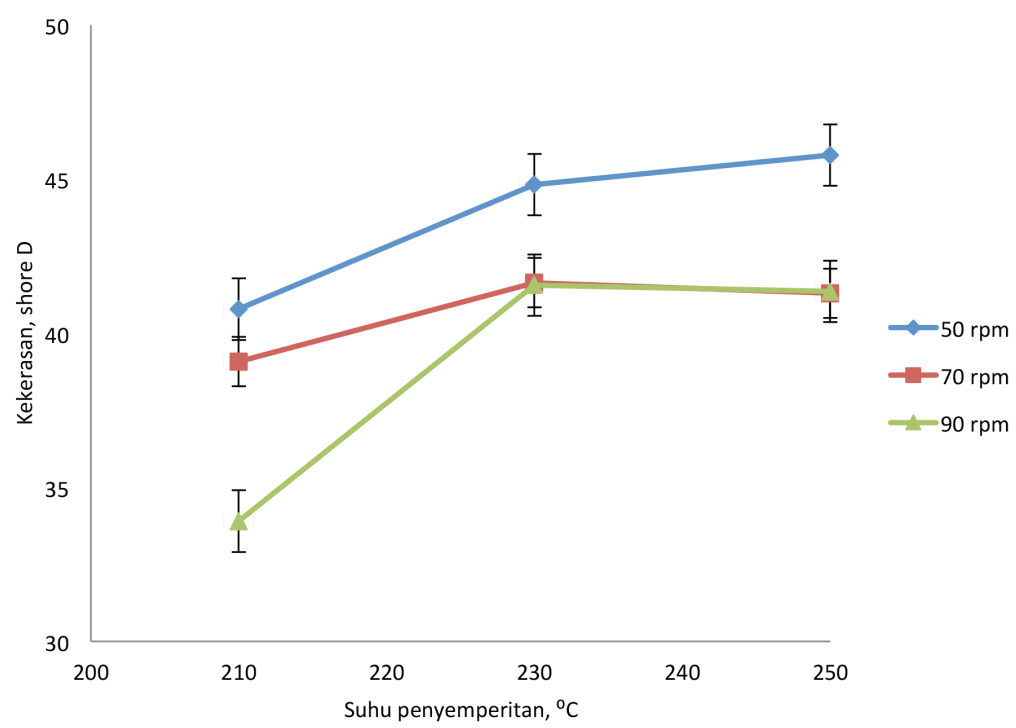

RAJAH 7. Nilai kekerasan bahan komposit MCF/PP

dalam Rajah 6(a). Ini kerana penyerakan pengisi dalam polimer matriks didorong oleh tegasan ricih kesan daripada proses penyemperitan (Antunes et al. 201; Balberg 2002; Fan \& Advani 20051; Pötschke et al. 2004; Tang et al. 2003). Kekurangan penyerakan ini sekali gus mengurangkan kadar orientasi pengisi dalam komposit yang dapat diperhatikan dengan jelas dalam Rajah 6(a) dan 6(b) dengan pengisi pengalir lebih panjang pada suhu $210^{\circ} \mathrm{C}$ berbanding pada suhu $230^{\circ} \mathrm{C}$ (Kim et al. 2006; Wang et al. 2011).

Kekerasan bahan adalah salah satu sifat mekanik yang penting bagi komposit polimer pengalir. Rajah 7 menunjukkan kesan peningkatan halaju putaran dan suhu penyemperitan ke atas kekerasan bahan komposit pengalir. Keputusan ujian kekerasan adalah sama dengan ujian keberaliran elektrik dengan komposit pada halaju 50 rpm meningkat daripada 41 kepada 46 apabila suhu penyemperitan meningkat. Berbeza dengan halaju putaran pada 70 dan $90 \mathrm{rpm}$, kekerasan bahan menurun disebabkan bahan berkumpul dan tidak berserak dengan sekata (Zakaria et al. 2015).

\section{KESIMPULAN}

Kaedah Taguchi digunakan bagi mengoptimumkan proses penyemperitan komposit polimer pengalir serta meningkatkan prestasi keberaliran elektrik. Pengoptimuman parameter penyemperitan adalah pada suhu penyemperitan, $230^{\circ} \mathrm{C}$ serta halaju putaran pada $50 \mathrm{rpm}$ dengan keberaliran elektrik paling tinggi pada $3.7 \mathrm{~S} / \mathrm{cm}$. Peningkatan suhu penyemperitan halaju putaran dilihat tidak memberikan kesan terhadap orientasi pengisi sebaliknya menurunkan tahap keberaliran elektrik kesan daripada pengisi yang tidak berserak dengan sempurna dalam matriks polimer. Selain itu, kajian mendapati halaju putaran yang tinggi menyumbang kepada patah pengisi pengalir pada tahap melampau yang dapat diperhatikan melalui pemerhatian mikroskop.

\section{PENGHARGAAN}

Penulis ingin merakamkan setinggi-tinggi terima kasih kepada Kementerian Pendidikan Tinggi Malaysia (KPT) bagi pembiayaan di bawah nombor geran FRGS/1/2013/ TK04/UKM/01/2 dan program MyBrain15.

\section{RUJUKAN}

Antunes, R.A., de Oliveira, M.C.L.,Ett, G. \& Ett, V. 2011 .Carbon materials in composite bipolar plates for polymer electrolyte membrane fuel cells: A review of the main challenges to improve electrical performance. Journal of Power Sources 196(6): 2945-2961.

Arslanoglu, N. \& Yigit, A. 2016. Experimental investigation of radiation effect on human thermal comfort by Taguchi method. Applied Thermal Engineering 92: 18-23.

Ausias, G., Jarrin, J. \& Vincent, M. 1996. Optimization of the tube-extrusion die for short-fiber-filled polymers. Composites Science and Technology 56(7): 719-724.

Balberg, I. 2002. A comprehensive picture of the electrical phenomena in carbon black-polymer composites. Carbon 40(2): 139-143.

Balogun, Y.A. \& Buchanan, R.C. 2010. Enhanced percolative properties from partial solubility dispersion of filler phase in conducting polymer composites (CPCs). Composites Science and Technology 70(6): 892-900.

Barton, R., Keith, J. \& King, J. 2008. Electrical conductivity modeling of multiple carbon fillers in liquid crystal polymer composites for fuel cell bipolar plate applications. J. New Mater. Electrochem. Syst. 11(3): 181.

Barton, R., Keith, J. \& King, J. 2007. Development and modeling of electrically conductive carbon filled liquid crystal polymer composites for fuel cell bipolar plate applications. Journal of New Materials for Electrochemical Systems 10(4): 225.

Chua, M.I.H., Sulong, A.B., Abdullah, M.F. \& Muhamad, N. 2013. Optimization of injection molding and solvent debinding parameters of stainless steel powder (SS316L) based feedstock for metal injection molding. Sains Malaysiana 42(12): 1743-1750. 
Dweiri, R. \& Sahari, J. 2008. Microstructural image analysis and structure-electrical conductivity relationship of single- and multiple-filler conductive composites. Composites Science and Technology 68(7-8): 1679-1687.

Dweiri, R. \& Sahari, J. 2007. Electrical properties of carbonbased polypropylene composites for bipolar plates in polymer electrolyte membrane fuel cell (PEMFC). Journal of Power Sources 171(2): 424-432.

Fan, Z. \& Advani, S.G. 2005. Characterization of orientation state of carbon nanotubes in shear flow. Polymer 46(14): 5232-5240.

Feller, J.F., Chauvelon, P., Linossier, I. \& Glouannec, P. 2003. Characterization of electrical and thermal properties of extruded tapes of thermoplastic conductive polymer composites (CPC). Polymer Testing 22(7): 831-837.

Feller, J.F., Linossier, I. \& Grohens, Y. 2002. Conductive polymer composites: Comparative study of poly(ester)-short carbon fibres and poly(epoxy)-short carbon fibres mechanical and electrical properties. Materials Letters 57(1): 64-71.

Hine, P.J., Davidson, N., Duckett, R.A. \& Ward, I.M. 1995. Measuring the fibre orientation and modelling the elastic properties of injection-moulded long-glass-fibre-reinforced nylon. Composites Science and Technology 53(2): 125-131.

Hobbie, E.K., Wang, H., Kim, H., Lin-Gibson, S \& \& Grulke, E.A. 2003. Orientation of carbon nanotubes in a sheared polymer melt. Physics of Fluids (1994-present) 15(5): 1196-1202.

Hu, N., Masuda, Z., Yamamoto, G., Fukunaga, H., Hashida, T. \& Qiu, J. 2008. Effect of fabrication process on electrical properties of polymer/multi-wall carbon nanotube nanocomposites. Composites Part A: Applied Science and Manufacturing 39(5): 893-903.

Ibrahim, M., Muhamad, N., Sulong, A.B., Jamaludin, K., Ahmada, S. \& Norb, N. 2010. Optimization of micro metal injection molding for highest green strength by using Taguchi method. International Journal of Mechanical and Materials Engineering 5(2): 282-289.

Jimenez, G.A. \& Jana, S.C. 2007. Electrically conductive polymer nanocomposites of polymethylmethacrylate and carbon nanofibers prepared by chaotic mixing. Composites Part A: Applied Science and Manufacturing 38(3): 983-993.

Kakati, B.K., Sathiyamoorthy, D. \& Verma, A. 2011. Semiempirical modeling of electrical conductivity for composite bipolar plate with multiple reinforcements. International Journal of Hydrogen Energy 36(22): 14851-14857.

Kakati,B.K., Yamsani, V.K.,Dhathathreyan, K.S., Sathiyamoorthy, D. \& Verma, A. 2009. The electrical conductivity of a composite bipolar plate for fuel cell applications. Carbon 47(10): 2413-2418.

Kaytakoğlu, S. \& Akyalçın, L. 2007. Optimization of parametric performance of a PEMFC. International Journal of Hydrogen Energy 32(17): 4418-4423.

Kim, Y.A., Hayashi, T., Endo, M., Gotoh, Y., Wada, N. \& Seiyama, J. 2006. Fabrication of aligned carbon nanotubefilled rubber composite. Scripta Materialia 54(1): 31-35.

Köpplmayr, T., Milosavljevic, I., Aigner, M., Hasslacher, R., Plank, B., Salaberger, D. \& Miethlinger, J. 2013. Influence of fiber orientation and length distribution on the rheological characterization of glass-fiber-filled polypropylene. Polymer Testing 32(3): 535-544.

Li, Y., Liu, H., Dai, K., Zheng, G., Liu, C., Chen, J. \& Shen, C. 2015. Tuning of vapor sensing behaviors of eco-friendly conductive polymer composites utilizing ramie fiber. Sensors and Actuators B: Chemical 221: 1279-1289.
Merzouki, A. \& Haddaoui, N. 2012. Electrical conductivity modeling of polypropylene composites filled with carbon black and acetylene black. ISRN Polymer Science 2012: Article ID. 493065.

Nakayama, Y., Takeda, E., Shigeishi, T., Tomiyama, H. \& Kajiwara, T. 2011. Melt-mixing by novel pitched-tip kneading disks in a co-rotating twin-screw extruder. Chemical Engineering Science 66(1): 103-110.

Pötschke, P., Bhattacharyya, A.R. \& Janke, A. 2004. Melt mixing of polycarbonate with multiwalled carbon nanotubes: Microscopic studies on the state of dispersion. European Polymer Journal 40(1): 137-148.

Pourjafar, S., Jahanshahi, M. \& Rahimpour, A. 2013. Optimization of $\mathrm{TiO} 2$ modified poly(vinyl alcohol) thin film composite nanofiltration membranes using Taguchi method. Desalination 315: 107-114.

Suherman, H., Sahari, J. \& Sulong, A.B. 2013. Effect of small-sized conductive filler on the properties of an epoxy composite for a bipolar plate in a PEMFC. Ceramics International 39(6): 7159-7166

Suherman, H., Sulong, A.B. \& Sahari, J. 2013. Effect of the compression molding parameters on the in-plane and through-plane conductivity of carbon nanotubes/graphite/ epoxy nanocomposites as bipolar plate material for a polymer electrolyte membrane fuel cell. Ceramics International 39(2): 1277-1284

Sulong, A.B., Ramli, M.I., Hau, S.L., Sahari, J., Muhamad, N. \& Suherman, H. 2013. Rheological and mechanical properties of carbon nanotube/Graphite/SS316L/polypropylene nanocomposite for a conductive polymer composite. Composites Part B: Engineering 50(0): 54-61.

Taherian, R., Hadianfard, M.J. \& Golikand, A.N. 2013. A new equation for predicting electrical conductivity of carbon-filled polymer composites used for bipolar plates of fuel cells. Journal of Applied Polymer Science 128(3): 1497-1509.

Taipalus, R., Harmia, T., Zhang, M.Q. \& Friedrich, K. 2001. The electrical conductivity of carbon-fibre-reinforced polypropylene/polyaniline complex-blends: Experimental characterisation and modelling. Composites Science and Technology 61(6): 801-814.

Takeda, T., Shindo, Y., Kuronuma, Y. \& Narita, F. 2011. Modeling and characterization of the electrical conductivity of carbon nanotube-based polymer composites. Polymer 52(17): 3852-3856

Tang, W., Santare, M.H. \& Advani, S.G. 2003. Melt processing and mechanical property characterization of multi-walled carbon nanotube/high density polyethylene (MWNT/HDPE) composite films. Carbon 41(14): 2779-2785.

Tungjitpornkull, S. \& Sombatsompop, N. 2009. Processing technique and fiber orientation angle affecting the mechanical properties of E-glass fiber reinforced wood/PVC composites. Journal of Materials Processing Technology 209(6): 30793088 .

Wang, J., Geng, C., Luo, F., Liu, Y., Wang, K., Fu, Q. \& He, B. 2011. Shear induced fiber orientation, fiber breakage and matrix molecular orientation in long glass fiber reinforced polypropylene composites. Materials Science and Engineering: A 528(7-8): 3169-3176.

Yusoff, M., Zuhri, M., Salit, M.S., Ismail, N. \& Wirawan, R. 2010. Mechanical properties of short random oil palm fibre reinforced epoxy composites. Sains Malaysiana 39(1): 87-92.

Zakaria, M.Y., Sulong, A.B., Sahari, J. \& Suherman, H. 2015. Effect of the addition of milled carbon fiber as a secondary 
filler on the electrical conductivity of graphite/epoxy composites for electrical conductive material. Composites Part B: Engineering 83: 75-80.

Nabilah Afiqah Mohd Radzuan*,Abu Bakar Sulong \& Mahendra Rao Somalu

Institut Sel Fuel

Universiti Kebangsaan Malaysia

43600 Bangi, Selangor Darul Ehsan

Malaysia

\section{Abu Bakar Sulong}

Jabatan Kejuruteraan Mekanik dan Bahan

Universiti Kebangsaan Malaysia

43600 Bangi, Selangor Darul Ehsan

Malaysia
*Pengarang untuk surat-menyurat; email: afiqahmradzuan@ gmail.com

Diserahkan: 14 April 2016

Diterima: 12 Oktober 2016 